\title{
The Application of Arsenic Trioxide in Ameliorating ABT-737 Target Therapy on Uterine Cervical Cancer Cells through Unique Pathways in Cell Death
}

\author{
I-Lun Hsin ${ }^{1,+}$, Ying-Hsiang Chou ${ }^{1,2,3,+}{ }^{\mathbb{D}}$, Wei-Li Hung ${ }^{1}$, Jiunn-Liang Ko ${ }^{1}$ and \\ Po-Hui Wang 1,4,5,6,* \\ 1 Institute of Medicine, Chung Shan Medical University, Taichung 40201, Taiwan; \\ zontetsuken@gmail.com (I-L.H.); hideka.chou@gmail.com (Y.-H.C.); ayuatsushi@hotmail.com (W.-L.H.); \\ jlko@csmu.edu.tw (J.-L.K.) \\ 2 Department of Medical Imaging and Radiological Sciences, Chung Shan Medical University, \\ Taichung 40201, Taiwan \\ 3 Department of Radiation Oncology, Chung Shan Medical University Hospital, Taichung 40201, Taiwan \\ 4 Department of Obstetrics and Gynecology, Chung Shan Medical University Hospital, \\ Taichung 40201, Taiwan \\ 5 School of Medicine, Chung Shan Medical University, Taichung 40201, Taiwan \\ 6 Department of Medical Research, Chung Shan Medical University Hospital, Taichung 40201, Taiwan \\ * Correspondence: wang082160@gmail.com; Tel.: +886-4-24739595 (ext. 21721); Fax: +886-4-24738493 \\ + These authors contributed equally to this work.
}

Received: 16 December 2019; Accepted: 29 December 2019; Published: 31 December 2019

\begin{abstract}
ABT-737, a B cell lymphoma-2 (Bcl-2) family inhibitor, activates apoptosis in cancer cells. Arsenic trioxide is an apoptosis activator that impairs cancer cell survival. The aim of this study was to evaluate the effect of a combination treatment with ABT-737 and arsenic trioxide on uterine cervical cancer cells. MTT (3-(4,5-dimethylthiazol-2-yl)-25-diphenyltetrazolium bromide) assay revealed that ABT-737 and arsenic trioxide induced a synergistic effect on uterine cervical cancer cells. Arsenic trioxide enhanced ABT-737-induced apoptosis and caspase-7 activation and the ABT-737-mediated reduction of anti-apoptotic protein Mcl-1 in Caski cells. Western blot assay revealed that arsenic trioxide promoted the ABT-737-mediated reduction of CDK6 and thymidylate synthetase in Caski cells. Arsenic trioxide promoted ABT-737-inhibited mitochondrial membrane potential and ABT-737-inhibited ANT expression in Caski cells. However, ABT-737-elicited reactive oxygen species were not enhanced by arsenic trioxide. The combined treatment induced an anti-apoptosis autophagy in SiHa cells. This study is the first to demonstrate that a combination treatment with ABT-737 and arsenic trioxide induces a synergistic effect on uterine cervical cancer cells through apoptosis. Our findings provide new insights into uterine cervical cancer treatment.
\end{abstract}

Keywords: ABT-737; apoptosis; arsenic trioxide; autophagy; uterine cervical cancer

\section{Introduction}

B cell lymphoma-2 (Bcl-2) homology 3 (BH3) exhibits pro-apoptotic functions either by directly inducing $\mathrm{Bcl}-2$-associated $\mathrm{X}$ protein (Bax) and $\mathrm{Bcl}-2$ homologous antagonist/killer (Bak) or by displacing them away from inhibitory interactions with anti-apoptotic Bcl-2 family members [1]. 4-[4-[(4'-chloro[1,1'-biphenyl]-2-yl)methyl]-1-piperazinyl]-N-[[4-[[(1R)-3-(dimethylamino)-1-[(phen ylthio)methyl]propyl]amino]-3-nitrophenyl] sulfonyl]-benzamide (ABT-737) is one of the best-characterized $\mathrm{BH} 3$ mimetics. It targets and inhibits anti-apoptotic $\mathrm{Bcl}-2$ family proteins, such as Bcl-2 [2,3]. ABT-737 can induce intrinsic apoptosis pathway and reduce cell viability through 
Bax and Bak [4]. Cancer cells expressing high Bcl-2 levels are sensitive to ABT-737 treatment $[2,5,6]$, and ABT-737 combines with cytotoxic drugs against solid tumors and hematological malignancy and overcome cancer cell resistance [5-10].

Arsenic trioxide $\left(\mathrm{As}_{2} \mathrm{O}_{3}\right)$ has been applied as a therapeutic agent for more than 2400 years, and its preparation (trade name Trisenox) was approved for the treatment of acute promyelocytic leukemia by the U.S. Food and Drug Administration in September 2000 [11]. It can trigger the intrinsic pathway of apoptosis in human leukemia cells [12]. This apoptotic signaling is presented with oxidative stress, change in mitochondrial membrane potential, and upregulation of apoptotic proteins, leading to cell death. $\mathrm{As}_{2} \mathrm{O}_{3}$ can also induce apoptosis of the cancer cells of uterine cervix via the mitochondrial pathway [13], suppresses the migration and angiogenesis of gastric cancer cells [14], and reverses chemoresistance in hepatocellular carcinoma [15].

Accumulating evidence suggests that the ratio between pro-apoptotic and anti-apoptotic Bcl-2 proteins determines the susceptibility of cancer cells, and cell apoptosis may be induced by inhibiting Bcl-2 [2,3,16-18]. A synergistic therapeutic effect on triple-negative breast cancer cell line MDA-MB-231 that overexpresses Bcl-2 can be achieved by combining ABT-737 with docetaxel [10]. In the present study, we investigated a novel treatment strategy that enhances the unique pathways of ABT-737 other than Bax and Bak to determine novel pathways and augment their effects that kill cancer cells in uterine cervixes. In the 2014 Annual Report of Taiwan Cancer Registry, cervical cancer was the second most common type of gynecological cancer and the eighth most frequent cause of female malignancy. It accounted for the age-standardized incidence rate of 8.50 per 100,000 women and a mortality rate of 3.39 in 2014. We hypothesize that the combined treatment of ABT-737 and arsenic trioxide reduces cancer cell viability and enhances the therapeutic effect of both drugs on cervical cancer. The aim of this study was to validate the synergic effect of ABT-737 and arsenic trioxide on cervical cancer cells and develop treatment strategies for this cancer. The pathways through which they promote cancer cell death were determined.

\section{Materials and Methods}

\subsection{Cell Culture and Chemicals}

Caski and SiHa cervical cancer cell lines were obtained from the American Type Tissue Culture Collection. The Caski cells were cultured in Roswell Park Memorial Institute 1640 medium supplemented with 10\% heat-inactivated fetal bovine serum (FBS), $0.2 \%$ sodium bicarbonate, 2 $\mathrm{mM}$ L-glutamine, $100 \mathrm{U} / \mathrm{mL}$ penicillin, and $100 \mu \mathrm{g} / \mathrm{mL}$ streptomycin. The SiHa cells were cultured in Dulbecco's Modified Eagle Medium with 10\% FBS, 5.5\% sodium bicarbonate, 2 mM L-glutamine, 100 $\mathrm{U} / \mathrm{mL}$ penicillin, and $100 \mu \mathrm{g} / \mathrm{mL}$ streptomycin. $\mathrm{As}_{2} \mathrm{O}_{3}, 3$-methyladenine (3-MA), and chloroquine were purchased from Sigma (St. Louis, MO, USA). ABT-737 was obtained from Cayman (Ann Arbor, MI, USA).

MTT (3-(4,5-dimethylthiazol-2-yl)-25-diphenyltetrazolium bromide) assay (MTT assay). The Caski and SiHa cells $\left(5 \times 10^{3}\right.$ cells/well $)$ were seeded into a 96-well plate with a $100 \mu \mathrm{L}$ culture medium. The medium was removed after treatment for $48 \mathrm{~h}$, and $100 \mu \mathrm{L}$ of the medium containing $0.5 \mathrm{mg} / \mathrm{mL}$ MTT (Sigma, M 2128) was added. MTT assay was performed as previously described [19]. The combination index was calculated using the software Compusyn 1.0. [20].

\subsection{Flow Cytometry for Apoptosis}

The Caski and SiHa cells $\left(2 \times 10^{5}\right.$ cells) were seeded onto a $60 \mathrm{~mm}$ dish containing $5 \mathrm{~mL}$ of culture medium. The medium was removed after $24 \mathrm{~h}$ incubation, and $5 \mathrm{~mL}$ of fresh medium containing $\mathrm{As}_{2} \mathrm{O}_{3}$ and ABT-737 was added to the dish. The cells were used in investigating apoptosis after $48 \mathrm{~h}$ of treatment. Apoptosis was analyzed with fluorescein isothiocyanate (FITC)-labeled annexin V and propidium iodide (PI). A FITC-annexin V apoptosis detection kit I (BD Pharmingen ${ }^{\mathrm{TM}}$, San Diego, CA, USA; BD Biosciences, San Jose, CA, USA) was used. 


\subsection{Detection of Mitochondrial Membrane Potential (MMP, $\triangle \Psi m$ )}

About $5 \times 10^{5}$ cells CaSki or SiHa cells were seeded onto a $60 \mathrm{~mm}$ dish containing $5 \mathrm{~mL}$ of culture medium. ABT-737 $(2.5$ or $5.0 \mu \mathrm{M})$ or $\mathrm{As}_{2} \mathrm{O}_{3}(2.0 \mu \mathrm{M})$ was added $48 \mathrm{~h}$. At 30 min prior to harvesting, these cells were stained at $37{ }^{\circ} \mathrm{C}$ using a $2.5-\mu \mathrm{M}$ final concentration of 5,5,6,6' -tetrachloro-1,1,3,3' -tetraethylbenzimi-dazolylcarbocy-anine iodide dye (JC-1, T3168, Invitrogen, Carlsbad, CA, USA; Thermo Fisher Scientific, Inc., San Jose, CA, USA) to detect the MMP by fluorescence microscopy and flow cytometry using CellQuest 5.1 software (BD Biosciences, San Jose, CA, USA).

\subsection{Detection of Reactive Oxygen Species (ROS)}

The amount of $\mathrm{H}_{2} \mathrm{O}_{2}$ was determined on the basis of fluorescent light detection for oxidative stress by flow cytometry based on the oxidization and then the conversion of $2^{\prime}, 7^{\prime}$-dichlorodihydrofluorescein diacetate dye (H2DCFDA; Invitrogen; Thermo Fisher Scientific, Inc., San Jose, CA, USA) into fluorescent $2^{\prime}, 7^{\prime}$-dichloro-fluorescein by intracellular ROS. The complete protocols for these analyses are described elsewhere [21,22].

\subsection{Western Blot Analysis}

Anti-cleaved caspase-7 (\#9491, Cell Signaling, Danvers, MA, USA), anti-myeloid cell leukemia 1 (\#39224, Cell Signaling), anti-Bax (\#2772, Cell Signaling), anti-Bak (\#12105, Cell Signaling), anti-cyclin-dependent kinase 6 (GTX-103992, Genetex, Irvine, CA, USA), anti-thymidylate synthase (GTX-113289, Genetex, Irvine, CA, USA), anti-voltage-dependent anion channel 1 (Ab14734, Abcam, Cambridge, UK), anti-light chain 3B (\#3868, Cell Signaling), anti-adenine nucleotide translocase (SC-9300, Santa Cruz, CA, USA), and anti- $\beta$-actin (Sigma, St. Louis, MI, USA) were used to detect the protein expression levels of the indicated genes. The complete protocols for Western blot assay are described in a previous publication [23].

\section{Results}

3.1. Synergistic Cell Death Induced by Combing ABT-737 with Arsenic Trioxide as Compared to Single Arsenic Trioxide or $A B T-737$

MTT assay revealed that the ratios of cell viability of the SiHa cancer cells were $82.8 \%, 74.0 \%$, and $37.8 \%$ after a single treatment of $1.25,2.5$, and $5 \mu \mathrm{M}$ ABT-737, respectively, and the survival rates after treatment of 0,2 , and $8 \mu \mathrm{M} \mathrm{As}_{2} \mathrm{O}_{3}$ alone were $100 \%, 91.8 \%$, and $76 \%$, respectively (Figure $1 \mathrm{~A}$ ). After the combined treatment of $1.25,2.5$, and $5 \mu \mathrm{M} \mathrm{ABT}-737$ and $2 \mu \mathrm{M} \mathrm{As} \mathrm{S}_{2} \mathrm{O}_{3}$, the survival rates of SiHa cancer cells were $69.6 \%, 40.6 \%$, and $11.4 \%$, respectively; after the combined treatment of $1.25,2.5$, and $5 \mu \mathrm{M}$ ABT-737 and $8 \mu \mathrm{M} \mathrm{As}_{2} \mathrm{O}_{3}$, the survival rates were $42.7 \%, 20.4 \%$, and $12.5 \%$, respectively. The ratios of cell viability of Caski cervical cancer cells after a single treatment of 1.25, 2.5, and $5 \mu \mathrm{M} \mathrm{ABT-737}$ alone were $96.6 \%, 69.9 \%$, and $23.7 \%$, respectively, and the survival rates after treatment with 0,2 , and $8 \mu \mathrm{M}$ $\mathrm{As}_{2} \mathrm{O}_{3}$ were $100 \%, 69.1 \%$, and 53.7\%, respectively (Figure 1B). After the combined treatment of 1.25, 2.5, and $5 \mu \mathrm{M}$ ABT-737 and $2 \mu \mathrm{M} \mathrm{As}{ }_{2} \mathrm{O}_{3}$, the survival rates of the Caski cancer cells were 39.3\%, 25.6\%, and $14.7 \%$, respectively. After the combined treatment of $1.25,2.5$, and $5 \mu \mathrm{M}$ ABT-737 and $8 \mu \mathrm{M} \mathrm{As} 2 \mathrm{O}_{3}$, the survival rates were $26.3 \%, 18.9 \%$, and $15 \%$, respectively. The combined effects of ABT-737 and $\mathrm{As}_{2} \mathrm{O}_{3}$ were evaluated on the basis of a combination index. In the SiHa and Caski cells, the combined treatment of $\mathrm{ABT}-737$ and $\mathrm{As}_{2} \mathrm{O}_{3}$ manifested synergistic inhibitory effects (combination index of $<0.9$; Figure $1 \mathrm{C}, \mathrm{D})$, and cell viability was observed in nonmalignant cells. This combined treatment did not considerably decrease cell viability in the mouse embryonic fibroblast and human keratinocyte cell line HaCat cells (Figure S1). These results demonstrated that the combined treatment of ABT-737 and $\mathrm{As}_{2} \mathrm{O}_{3}$ induced synergistic inhibitory effects on cervical cancer cells. 
(A) $\mathrm{SiHa}$

(B) Caski
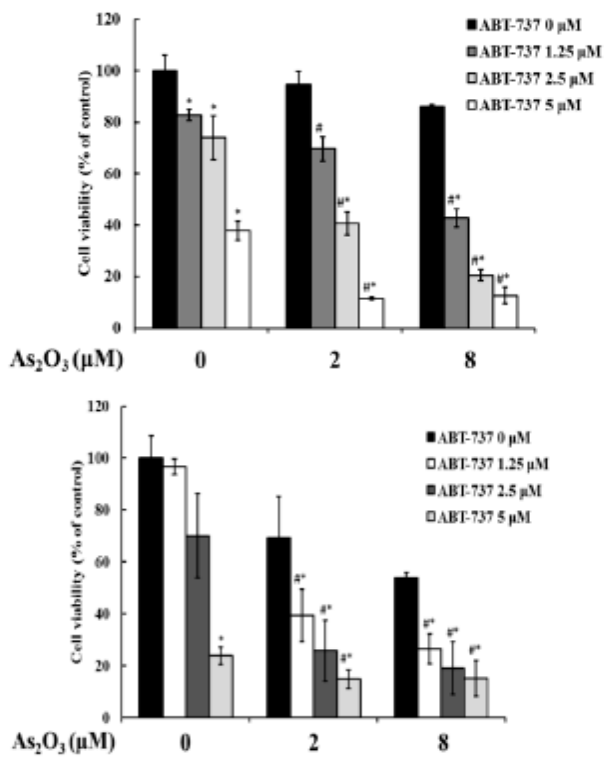

(C) $\mathrm{SiHa}$

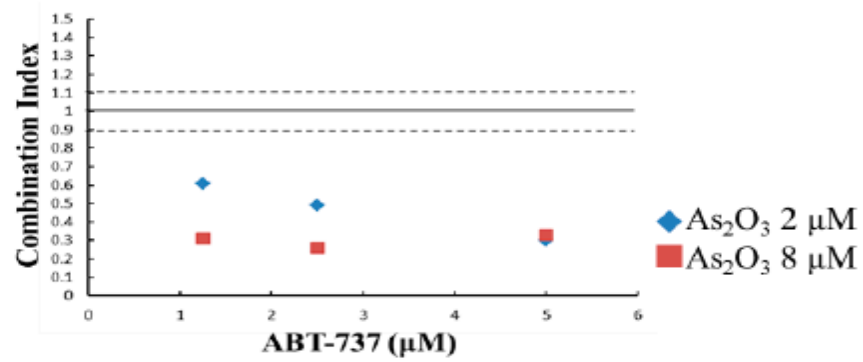

(D) Caski

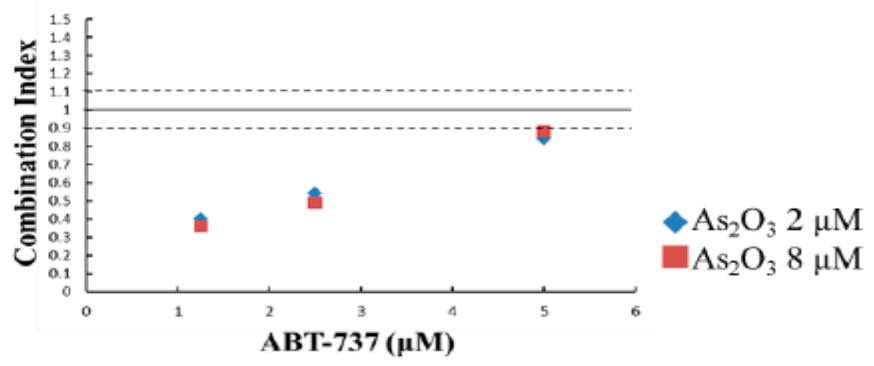

Figure 1. Effects of ABT-737 and $\mathrm{As}_{2} \mathrm{O}_{3}$ on cell viability in cervical cancer cells. (A) $\mathrm{SiHa}\left(5 \times 10^{3}\right.$ cells/96 wells) were treated with different concentrations of ABT-737 $(0,1.25,2.5,5 \mu \mathrm{M})$ and $\mathrm{As}_{2} \mathrm{O}_{3}(0$, $2,8 \mu \mathrm{M})$ for $48 \mathrm{~h}$. (B) Caski cells $\left(5 \times 10^{3}\right.$ cells/96 wells) were treated with different concentrations of ABT-737 $(0,1.25,2.5,5 \mu \mathrm{M})$ and $\mathrm{As}_{2} \mathrm{O}_{3}(0,2,8 \mu \mathrm{M})$ for $48 \mathrm{~h}$. The data were expressed as mean \pm SD. Significant differences were determined by one-way ANOVA. ${ }^{*} p<0.001$, compared with cells without treatment; \# $p<0.001$, compared with $\mathrm{A}_{\mathrm{s}} 2 \mathrm{O}_{3}$ individually treated but no ABT-737 treated cells. (C) Combination index of ABT-737 combined with $\mathrm{As}_{2} \mathrm{O}_{3}$ on SiHa cancer cells. (D) Combination index of ABT-737 combined with $\mathrm{As}_{2} \mathrm{O}_{3}$ on Caski cancer cells.

\subsection{Effect of ABT-737 Combined with $\mathrm{As}_{2} \mathrm{O}_{3}$ on Annexin V/PI Assay in Cervical Cancer Cells}

Cell death was investigated, and the underlying mechanism was analyzed by annexin V/PI assay. The combined treatment of ABT-737 and $\mathrm{As}_{2} \mathrm{O}_{3}$ increased the population of annexin $\mathrm{V}(+) / \mathrm{PI}(-)$ and annexin $\mathrm{V}(+) / \mathrm{PI}(+)$ in the $\mathrm{SiHa}$ and Caski cells. This result suggested that ABT-737 and $\mathrm{As}_{2} \mathrm{O}_{3}$ induced apoptotic cell death (Figure 2A). Changes in cleaved caspase-7 after ABT-737 and $\mathrm{As}_{2} \mathrm{O}_{3}$ treatment were observed through Western blot. The combined treatment of ABT-737 and $\mathrm{As}_{2} \mathrm{O}_{3}$ markedly increased cleaved caspase-7 levels in the SiHa cells. Unlike in the SiHa cells, cleaved caspase-7 was slightly upregulated in the Caski cells after the combined treatment as compared with that in separate treatments (Figure 2B). Surprisingly, Z-VAD-FMK, a pan-caspase inhibitor, minimally 
reversed cytotoxicity in both cells after ABT-737 single agent or combined treatment, but did not reverse cytotoxicity induced by treatment with $\mathrm{As}_{2} \mathrm{O}_{3}$ alone (Figure S2). These results, suggest that SiHa and Caski cells undergo a hybrid form of cell death involving partly apoptosis as well as a non-apoptotic caspase-independent cell death awaiting characterization.

\section{(A) $\mathrm{SiHa}$}

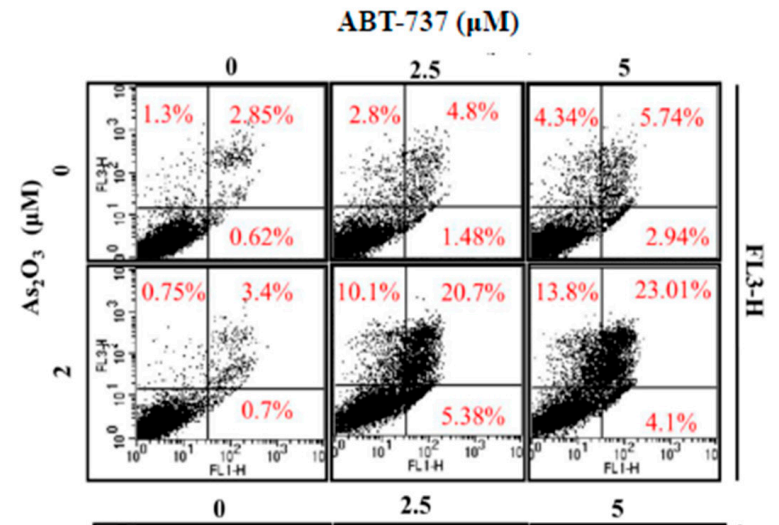

\section{Caski}

(B)

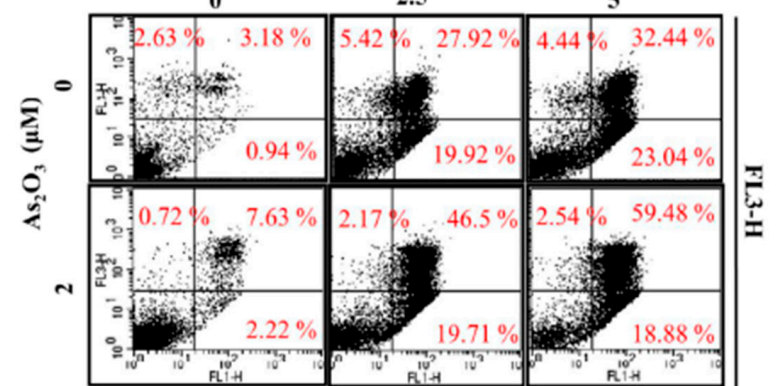

(C)

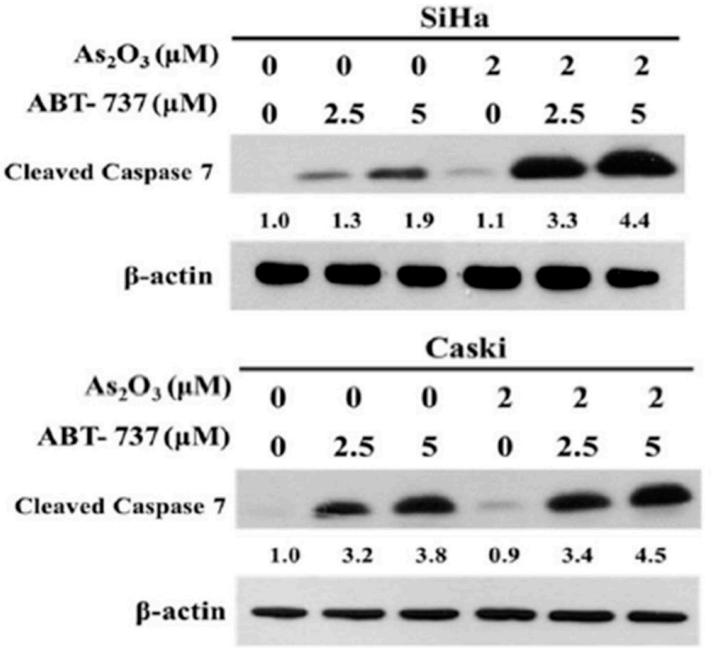

Figure 2. Effects of ABT-737 and $\mathrm{As}_{2} \mathrm{O}_{3}$ mediated apoptosis in cervical cancer cells. (A) SiHa and Caski cells $\left(4 \times 10^{5}\right.$ cells $/ 6 \mathrm{~cm}$ dish) were co-treated with ABT-737 and $\mathrm{As}_{2} \mathrm{O}_{3}$. The cells were stained with annexin V-fluorescein isothiocyanate (FITC)/propidium iodide (PI) and analyzed by flow cytometry. annexin V-FITC positive (early apoptosis) and annexin V-FITC/PI positive (late apoptosis) were quantified as apoptosis cells. $\mathrm{X}$ axis, annexin staining; $\mathrm{Y}$ axis, PI staining. (B) SiHa and (C) Caski cells $\left(4 \times 10^{5}\right.$ cells $/ 6 \mathrm{~cm}$ dish) were co-treated with $\mathrm{As}_{2} \mathrm{O}_{3}$ and ABT-737. Cleaved caspase-7 was detected by Western blot. $\beta$-actin was as a loading control. The relative ratio of cleaved caspase-7/ $\beta$-actin is shown.

\subsection{Effect of ABT-737 Combined with $A s_{2} \mathrm{O}_{3}$ on $M M P, \Delta \Psi m$}

JC-1 is a lipophilic mitochondrial agent that detects mitochondrial polarization. JC-1 stains the mitochondria in living cells in a membrane potential-dependent fashion. The so-called J-aggregates, which are favored at a high MMP (mitochondrial membrane potential) and present in the mitochondria, 
are in equilibrium with JC-1 monomers, which are favored at a low MMP level and present in the cytoplasm [24,25]. The ratio between J-aggregates and monomers was calculated for the analysis of MMP detected by flow cytometry (BD Biosciences, San Jose, CA, USA).

As shown in Figure 3A, MMP level was 7\% reduced by ABT-737 in the SiHa cells but not by the combination treatment. Unlike in the SiHa cells, the combined treatment of ABT-737 and $\mathrm{As}_{2} \mathrm{O}_{3}$ markedly reduced MMP level in the Caski cells (Figure 3A). The voltage-dependent anion channel 1 (VDAC1) did not substantially change after the separate treatment of ABT-737 or $\mathrm{As}_{2} \mathrm{O}_{3}$ in the SiHa and Caski cells (Figure 3B,C). ABT-737 decreased $\mathrm{As}_{2} \mathrm{O}_{3}$-induced adenine nucleotide translocase (ANT) upregulation in the SiHa cells (Figure 3B). The amount of ANT was reduced after the separate treatment of ABT-737 in the Caski cells (Figure 3C). Furthermore, ANT reduction was promoted after the combined treatment of ABT-737 and $\mathrm{As}_{2} \mathrm{O}_{3}$ in the Caski cells as compared with that in separate treatments (Figure 3C).

(A)

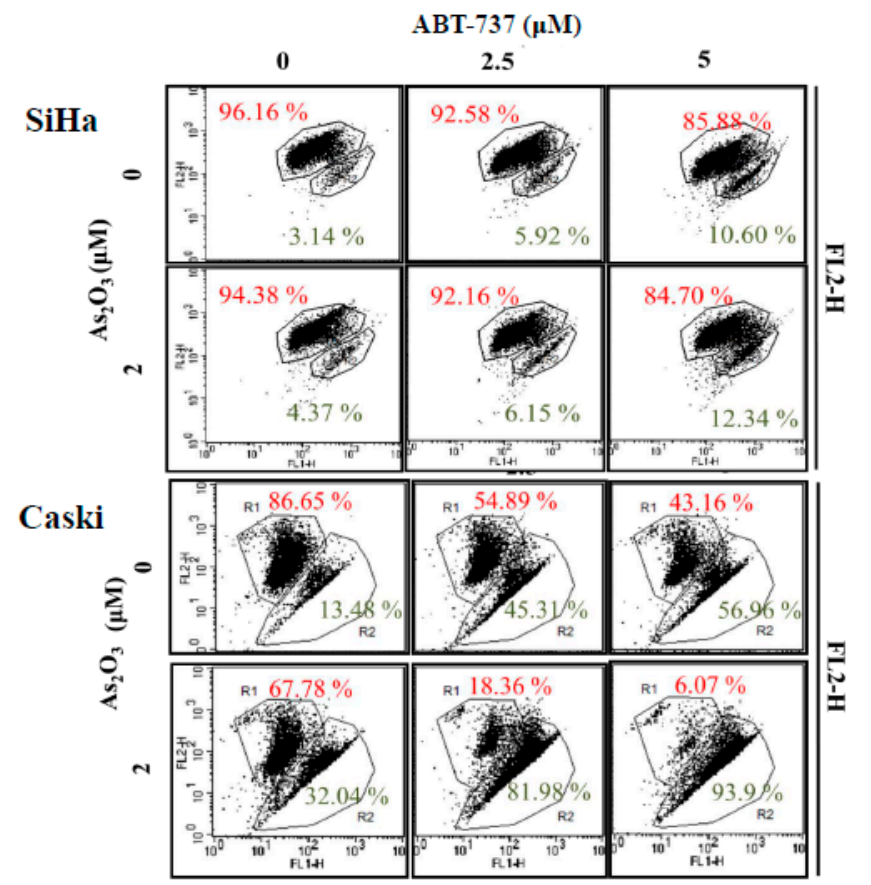

(B)

(C)

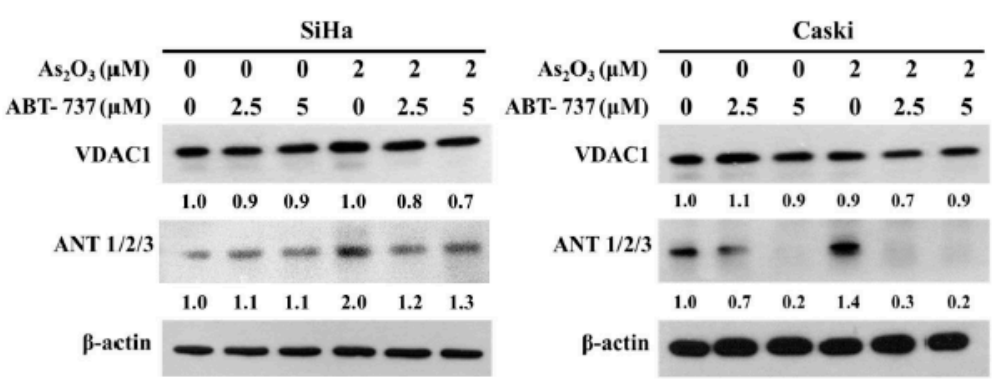

Figure 3. Effects of ABT-737 combined with $\mathrm{As}_{2} \mathrm{O}_{3}$ on mitochondrial membrane potential $(\Delta \Psi \mathrm{m})$ and mitochondrial membrane related proteins. (A) SiHa and Caski cells $\left(4 \times 10^{5}\right.$ cells $/ 6 \mathrm{~cm}$ dish) were combined with ABT-737 and $\mathrm{As}_{2} \mathrm{O}_{3}$ for $48 \mathrm{~h}$. The living cells were stained with 5,5,6,6'-tetrachloro-1,1,3,3' -tetraethylbenzimi-dazolylcarbocy-anine iodide (JC-1) dye to detect the mitochondrial membrane potential by flow cytometry. (B) SiHa and (C) Caski cells $\left(4 \times 10^{5} \mathrm{cells} / 6 \mathrm{~cm}\right.$ dish) were co-treated with ABT-737 and $\mathrm{As}_{2} \mathrm{O}_{3}$ for $48 \mathrm{~h}$. Voltage-dependent anion channel 1 (VDAC1) and adenine nucleotide translocase (ANT) $1 / 2 / 3$ were detected by Western blot. $\beta$-actin was used as a loading control. The relative ratio of VDAC $1 / \beta$-actin and ANT1/2/3/ $\beta$-actin are shown. 


\subsection{Effect of $A B T-737$ Combined with $\mathrm{As}_{2} \mathrm{O}_{3}$ on ROS}

The amount of $\mathrm{H}_{2} \mathrm{O}_{2}$ was determined on the basis of fluorescent light detection for oxidative stress by flow cytometry using a H2DCFDA dye. The ROS signal shifted to the right in the SiHa and Caski cells after ABT-737 was administered $8 \mathrm{~h}$ later. These results indicated that ABT-737 induced oxidative stress in the cervical cancer cells (Figure 4).

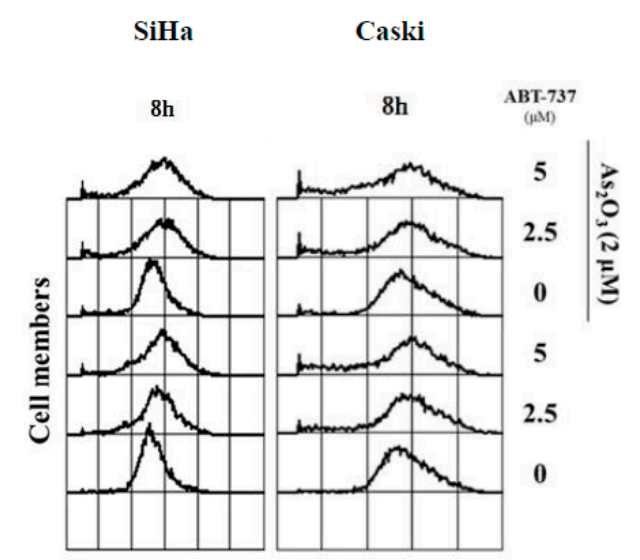

Figure 4. Effects of ABT-737 combined with $\mathrm{As}_{2} \mathrm{O}_{3}$ on reactive oxygen species (ROS) production in cervical cancer cells. SiHa cells $\left(4 \times 10^{5}\right.$ cells $/ 6 \mathrm{~cm}$ dish $)$ and Caski $\left(4 \times 10^{5}\right.$ cells $\left./ 6 \mathrm{~cm} \mathrm{dish}\right)$ were co-treated with ABT-737 and $\mathrm{As}_{2} \mathrm{O}_{3}$ for $8 \mathrm{~h}$. After treatment, the cells were stained with $2^{\prime}, 7^{\prime}$-dichlorodihydrofluorescein diacetate (H2DCFDA) dye to detect the production of ROS by flow cytometry.

3.5. Expressions of Anti-Apoptosis Proteins, Cell Cycle Regulated Protein CDK6 and DNA Synthesis TS after ABT-737 and $\mathrm{As}_{2} \mathrm{O}_{3}$ Co-Treatment

ABT-737 alone increased the expression levels of Mcl-1, and $\mathrm{As}_{2} \mathrm{O}_{3}$ alone decreased the ABT-737-induced Mcl-1 (Figure 5A). Unlike in the SiHa cells, ABT-737 alone reduced the expression levels of Mcl-1 in the Caski cells. Furthermore, the combined treatment remarkably decreased Mcl-1 expression in the Caski cells compared with the separate treatments (Figure 5B). The expression levels of Bax and Bak were not altered after the separate or combined treatments in both types of cancer cells (Figure 5A). CDK6 expression decreased after separate ABT-737 or $\mathrm{As}_{2} \mathrm{O}_{3}$ treatments in the $\mathrm{SiHa}$ cells (Figure 5C). The amount of TS in the SiHa cells was reduced by the combined treatment of ABT-737 and $\mathrm{As}_{2} \mathrm{O}_{3}$ (Figure $5 \mathrm{C}$ ). The amounts of CDK6 and TS in the Caski cells progressively decreased as the dose of ABT-737 increased (Figure 5D). After the combined treatment of ABT-737 and $\mathrm{As}_{2} \mathrm{O}_{3}$, the performance of both proteins decreased as the dose increased (Figure 5D). 
(A)

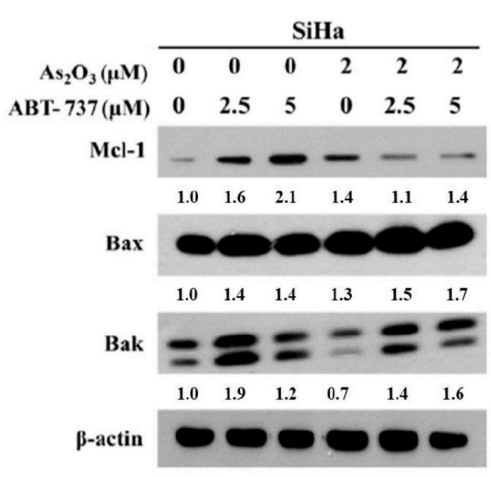

(C)

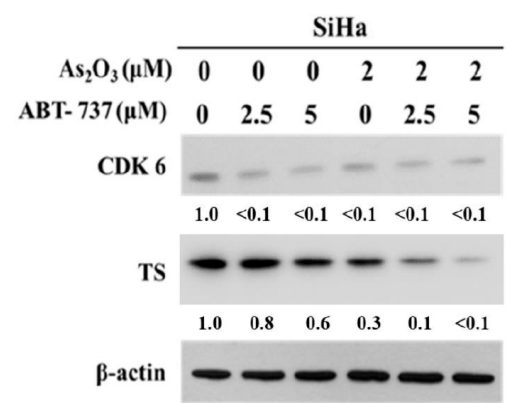

(B)

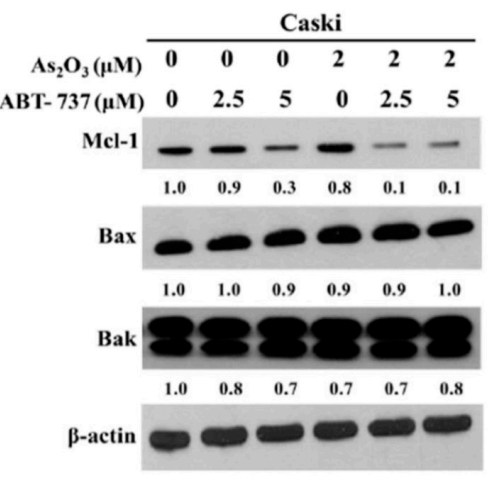

(D)

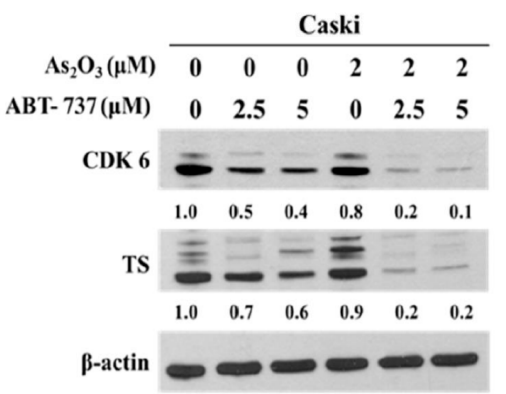

Figure 5. ABT-737 combined with $\mathrm{As}_{2} \mathrm{O}_{3}$ altered expression levels of anti-apoptosis proteins and cell cycle regulating protein. (A) SiHa and (B) Caski cells $\left(4 \times 10^{5}\right.$ cells $/ 6 \mathrm{~cm}$ dish) were combined with ABT-737 and $\mathrm{As}_{2} \mathrm{O}_{3}$ for $48 \mathrm{~h}$. Myeloid cell leukemia 1 (Mcl-1), Bcl-2-associated X protein (Bax) and Bcl-2 homologous antagonist/killer (Bak) were detected by Western blot. $\beta$-actin was as a loading control. The relative ratio of $\mathrm{Mcl}-1 / \beta$-actin, $\mathrm{BAX} / \beta$-actin, and Bak $/ \beta$-actin were shown. (C) SiHa and (D) Caski cells $\left(4 \times 10^{5}\right.$ cells $/ 6 \mathrm{~cm}$ dish) were combined with ABT-737 and $\mathrm{As}_{2} \mathrm{O}_{3}$ for $48 \mathrm{~h}$. Cyclin-dependent kinase 6 (CDK6) and thymidylate synthase (TS) were detected by Western blot. $\beta$-actin was as a loading control. The relative ratio of CDK6/ $\beta$-actin and TS/ $\beta$-actin are shown.

\subsection{Co-Treatment of ABT-737 and $\mathrm{As}_{2} \mathrm{O}_{3}$ Induced Anti-Apoptotic Autophagy in SiHa Cells}

Autophagy is an anti-apoptosis mechanism [26]. The combined treatment of ABT-737 and $\mathrm{As}_{2} \mathrm{O}_{3}$ increased the LC3B-II/LC3B-I ratio, suggesting that autophagy was induced in the SiHa cells after the treatment (Figure 6A). However, ABT-737 decreased the ratio of LC3B-II/LC3B-I in the Caski cells (Figure 6B). Furthermore, the $\mathrm{As}_{2} \mathrm{O}_{3}$-induced LC3B-II/LC3B-I ratio decreased because of ABT-737 (Figure 6B). To evaluate the role of autophagy as induced by the combined treatment of ABT-737 and $\mathrm{As}_{2} \mathrm{O}_{3}$ in activating apoptosis, we used the autophagy inhibitors 3-MA and chloroquine to inhibit autophagy in the SiHa cells. As shown in Figure 6C, 3-MA partially decreased the LC3B-II/LC3B-I ratio induced by $\mathrm{ABT}-737$ and $\mathrm{As}_{2} \mathrm{O}_{3}$. Compared with the combined treatment of $\mathrm{ABT}-737$ and $\mathrm{As}_{2} \mathrm{O}_{3}$, chloroquine increased the accumulation of LC3B-II, suggesting that the combined treatment induced autophagic flux in the SiHa cells (Figure 6C). Both autophagy inhibitors increased cleaved caspase-7 in the SiHa cells. This result showed that the combined treatment induced anti-apoptotic autophagy in the SiHa cells. 
(A)

(B)
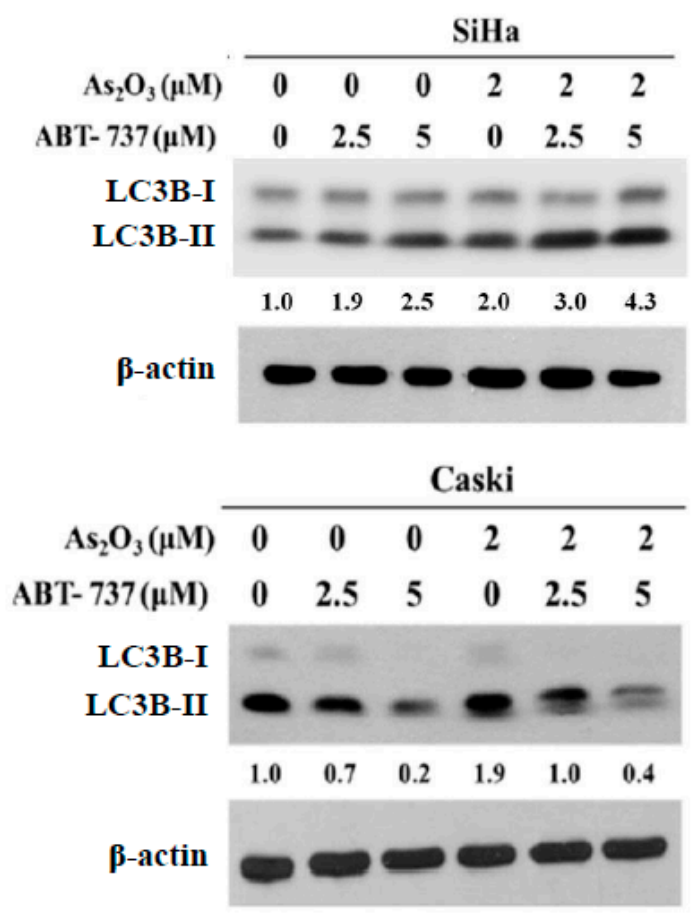

(C)

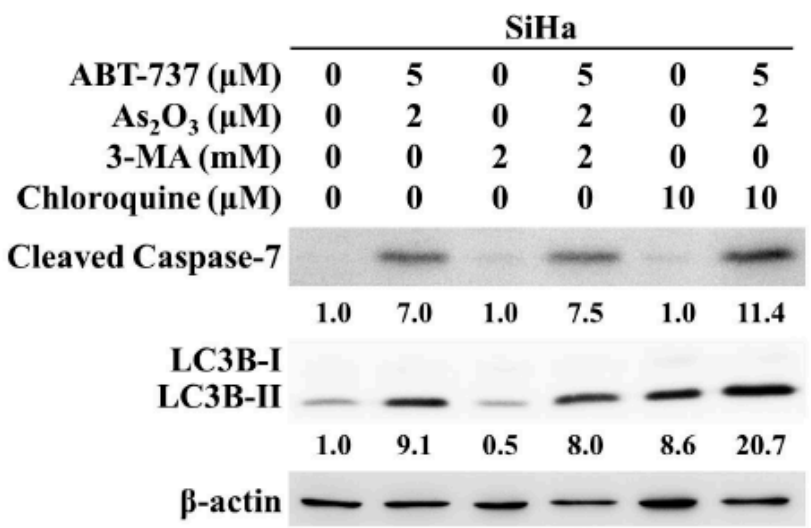

Figure 6. Effects of ABT-737 and $\mathrm{As}_{2} \mathrm{O}_{3}$ on autophagy induction in cervical cancer cells. (A) $\mathrm{SiHa}$ and (B) Caski cells $\left(4 \times 10^{5}\right.$ cells $/ 6 \mathrm{~cm}$ dish) were co-treated with ABT-737 and $\mathrm{As}_{2} \mathrm{O}_{3}$ for $48 \mathrm{~h}$. LC3B was detected by Western blot. $\beta$-actin was as a loading control. The relative ratio of LC3B II/LC3B I was shown. (C) After pretreatment of 3-MA for $1 \mathrm{~h}, \mathrm{ABT}-737, \mathrm{As}_{2} \mathrm{O}_{3}$, and chloroquine were treated for 48 h. LC3B and cleaved caspase-7 were detected by Western blot. $\beta$-actin was as a loading control. The relative ratio of LC3B-II/LC3B-I and cleaved caspase-7/ $\beta$-actin are shown.

\section{Discussion}

The action of ABT-737 on Bcl-2 has been demonstrated [2,3]. We explored the effects of ABT-737 on cervical cancer from a different perspective. Although the combination of ABT-737 with arsenic trioxide enhances cell apoptosis, their unique actions on cervical cancer cells were explored in other routes rather than the direct inhibition of Bcl-2. The unique actions of ABT-737 and arsenic trioxide on uterine cervical cancer are summarized in Figure 7. 


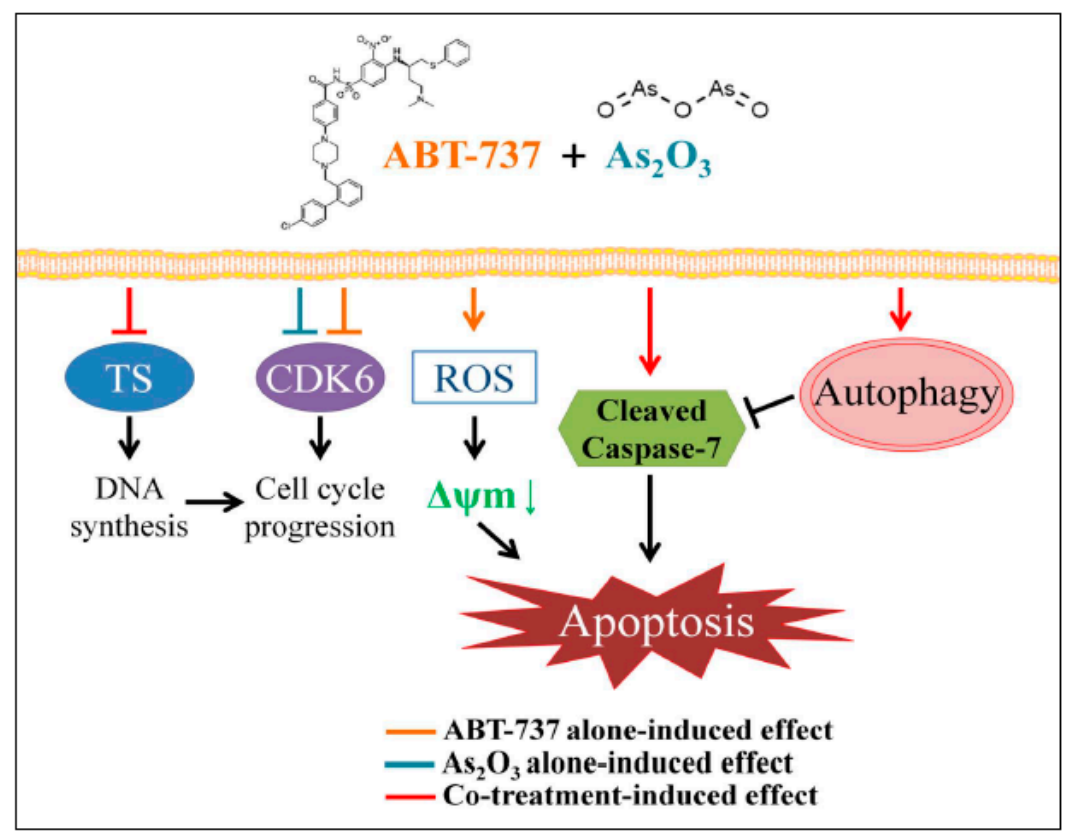

Figure 7. A suggested model of ABT-737 combined with $\mathrm{As}_{2} \mathrm{O}_{3}$ inducing cell death in SiHa cells.

We found that ABT-737 can induce cell death via different pathways other than Bax and Bak in Caski cervical cancer cells. ABT-737 augmented these actions after the combined treatment of $\mathrm{As}_{2} \mathrm{O}_{3}$ with synergistic effect. However, these effects are slightly different in SiHa cells. Aside from the Bax and Bak pathways, other pathways induce cell death in SiHa cells, which are more resistant to chemotherapy than Caski cells because $\mathrm{SiHa}$ cells exhibit higher levels of antioxidant enzymes [27]. Therefore, they may have different profiles to cytotoxic drugs. Caski cells, each containing 600 copies of the human papillomavirus 16 (HPV 16) genome, are more sensitive to cytokines than SiHa cells, which only have one or two copies of the HPV 16 genome [28]. Another study reported that SiHa cells present resistance to therapy from their early oncogenic protein HPV E6, causing host cell damage and then promoting cancer cell growth [29]. SiHa cell resistance can be reduced through p53 analogue p73 $\alpha$ overexpression. The present study implied that the stronger resistance of $\mathrm{SiHa}$ cells as compared with that of Caski cells may be overcome by the combined treatment of ABT-737 and $\mathrm{As}_{2} \mathrm{O}_{3}$. We have unique findings that ABT-737 can induce cell death via the pathways rather than Bax and Bak in Caski cervical cancer cells and augments these actions after co-treatment of $\mathrm{As}_{2} \mathrm{O}_{3}$ with synergistic effect. However, these effects are slightly diverse in SiHa cells. In addition to via Bax and Bak, other pathways are demonstrated to induce cell death in SiHa cells. SiHa cells were found to be more resistant to chemotherapy than Caski cells because SiHa cells exhibited higher levels of antioxidant enzyme [27]. Therefore, they may have potential to present different profiles to cytotoxic drugs. Caski cells, containing 600 copies of the human papillmovirus 16 (HPV 16) genome per cell were also found to be quite sensitive to the cytokine as compared to SiHa cells, with only one to two copies of the HPV 16 genome [28]. Another study found that SiHa cells present more resistant to therapy results from their early oncogenic protein HPV E6, causing host cells damage and then promoting cancer cell growth [29]. It revealed that SiHa cells resistance can be reduced through the p53 analogue, p73 $\alpha$ overexpression. Our study implied that the stronger resistance of SiHa cells than Caski cells may be overcome via combined ABT-737 and $\mathrm{As}_{2} \mathrm{O}_{3}$, exerting higher Bax and Bak expression and stronger synergistic effect in SiHa cells.

The amount of ANT in the Caski cells was substantially reduced after the combined treatment. This reduction is associated with the dissipation of MMP and the subsequent initiation of cell death. Hexokinase (HK) can bind to the outer mitochondrial membrane (OMM), especially to VDAC1; the outmost portion of the permeability transition pore complex (also known as the mitochondrial 
permeability transition pore (MPTP)) that is composed of VDAC1 at the OMM; ANT at the inner mitochondrial membrane (IMM); and cyclophilin D in the mitochondrial matrix [30,31]. Hexokinase II can convert glucose-6-phosphate, which is produced by HK in the cytoplasm, to ATP and glucose. ATP is transferred through the VDAC channel at OMM and ANT at IMM to maintain MMP $\Delta \Psi_{\mathrm{m}}$ in aerobic glycolysis, which is the principal process of energy supply for cancer cells [32,33]. When ANT is depleted, MMP is dissipated, and the permeability to MPTP increases [32]. This process leads to cytochrome $\mathrm{c}$ release and cell death. A previous study reported that non-small cell lung cancer with ANT overexpression may exhibit resistance to epidermal growth factor receptor/tyrosine kinase therapy [34]. Targeting ANT overcomes the resistance. In the present study, the expression levels of Bax increased after the combined treatment in the SiHa cells but they did not change in the Caski cells. However, Yu et al. found that $\mathrm{As}_{2} \mathrm{O}_{3}$ can trigger apoptosis associated with the dissociation of $\mathrm{Bcl}-2$ from Bax and VDAC and then release cytochrome $\mathrm{c}$ from Bax and the VDAC channel that is different from MPTP $[13,35]$. This process may rescue the lower ANT reduction in SiHa cells as compared with that in Caski cell for the combined treatment of ABT-737 and $\mathrm{As}_{2} \mathrm{O}_{3}$ in our experiments to promote cell death.

We found that Mcl-1 expression in Caski cells obviously decreased after the combined treatment. By contrast, the expression levels of Bax and Bak did not change. Vikström et al. reported that the loss of MCL-1 promotes Bcl-2 inhibition in long-lived plasma cell populations to ABT-737 in animal experiments [36]. Mcl-1 overexpression induces resistance against a number of widely-used anticancer therapies [37], such as paclitaxel [38], vincristine [38], and gemcitabine [39]. However, sensitivity to ABT-737 may be improved through the downregulation of Mcl-1 [40,41]. Furthermore, the combined treatment of ABT-737 and arsenic trioxide remarkably inhibits the xenograft growth of human gastric carcinoma cell lines SGC-7901, synergistically decreases tumor growth, and induces apoptosis in vivo [42]. Therefore, an attractive strategy and promising cancer target for anti-apoptotic Bcl-2 family members using ABT-737 can be applied in combination with additional treatment modalities [43].

Mitotic signals stimulate CDK4 and CDK6 activities, which promote cancer cell proliferation through the entrance of $\mathrm{G} 1$ into the $\mathrm{S}$ phase in cell cycle [44]. Only ABT-737 cannot arrest cell cycle. However, $\mathrm{As}_{2} \mathrm{O}_{3}$ can induce $\mathrm{G} 2 / \mathrm{M}$ arrest by $\mathrm{p} 21$ upregulation in acute promyelocytic leukemia [45]. CDK6 decreased after $\mathrm{As}_{2} \mathrm{O}_{3}$ was added for $72 \mathrm{~h}$. Thymidylate synthase participates in cell DNA synthesis [46]. Suppression of TS reduces intracellular thymidine. $\mathrm{As}_{2} \mathrm{O}_{3}$ can reportedly suppress TS in 5-fluorouracil-resistant colorectal cancer cell line HT29 and assumes its use as a chemosensitizer in combination therapy [47]. Therefore, the reduced expression of CDK6 and TS results in cell cycle arrest and defect in DNA synthesis and leads to cell degradation and apoptosis [48].

Autophagy can serve either as a pro-apoptosis or anti-apoptosis mechanism [49]. In the present study, the combined treatment of ABT-737 and $\mathrm{As}_{2} \mathrm{O}_{3}$ increased autophagy in the SiHa cells. Two inhibitors, namely, 3-MA and chloroquine were used to inhibit the different stages of autophagy. The combined treatment induced apoptosis-inhibiting autophagy. Chloroquine treatment increased LC3B-II accumulation in the SiHa cells after the combined treatment, suggesting that ABT-737 and $\mathrm{As}_{2} \mathrm{O}_{3}$ induce autophagic flux. Furthermore, ABT-737 induced apoptosis to a greater extent in the Caski cells than in SiHa cells. These results suggested that autophagy inhibition by ABT-737 increases ABT-737 sensitivity in Caski cells.

\section{Conclusions}

The combined treatment of ABT-737 and arsenic trioxide may exert a synergistic effect to induce the death of cervical cancer cells. The apoptotic ratio in the SiHa and Caski cells substantially increased after the combined treatment. ABT-737 and $\mathrm{As}_{2} \mathrm{O}_{3}$ cause ANT depletion and may simultaneously generate oxidative stress that will lead to MMP reduction [30,33]. These phenomena are sequentially involved in the activation of cleaved caspase-7. Meanwhile, aside from aggravating the above situations, they inhibit the expression of anti-apoptotic proteins and induce cell arrest through CDK6 reduction and interruption of DNA synthesis. Aside from the Bax and Bak pathways, a novel model of how 
ABT-737 and arsenic trioxide induce cervical cancer cell death in various ways is depicted. These mechanisms can be developed as novel therapeutic strategies for treating uterine cervical cancer.

Supplementary Materials: The following are available online at http://www.mdpi.com/2072-6694/12/1/108/s1, Figure S1: Effect of ABT-737 and $\mathrm{As}_{2} \mathrm{O}_{3}$ on cell viability in Mouse Embryonic Fibroblasts (MEF) and human keratinocyte cell line, HaCaT, Figure S2: Effect of pan-caspase inhibitor Z-VAD-FMK on cell viability in SiHa and Caski cells after ABT-737 and $\mathrm{As}_{2} \mathrm{O}_{3}$ treatment, Figure S3. Wetern blot.

Author Contributions: I-L.H., Y.-H.C., and W.-L.H. performed the experiments and analyzed the data. I-L.H. and P.-H.W. wrote the paper. J.-L.K. and P.-H.W. designed the experiments, provided crucial suggestions, and revised the paper. All authors have read and agreed to the published version of the manuscript.

Funding: This study was supported by research grants from Taiwan Ministry of Science and Technology (MOST 107-2314-B-040-017-MY3).

Conflicts of Interest: There are no conflicts of interest to declare.

\section{References}

1. Willis, S.N.; Adams, J.M. Life in the balance: How BH3-only proteins induce apoptosis. Curr. Opin. Cell Biol. 2005, 17, 617-625. [CrossRef] [PubMed]

2. Oltersdorf, T.; Elmore, S.W.; Shoemaker, A.R.; Armstrong, R.C.; Augeri, D.J.; Belli, B.A.; Bruncko, M.; Deckwerth, T.L.; Dinges, J.; Hajduk, P.J.; et al. An inhibitor of Bcl-2 family proteins induces regression of solid tumours. Nature 2005, 435, 677-681. [CrossRef]

3. Yecies, D.; Carlson, N.E.; Deng, J.; Letai, A. Acquired resistance to ABT-737 in lymphoma cells that up-regulate MCL-1 and BFL-1. Blood 2010, 115, 3304-3313. [CrossRef] [PubMed]

4. Chen, S.; Dai, Y.; Harada, H.; Dent, P.; Grant, S. Mcl-1 down-regulation potentiates ABT-737 lethality by cooperatively inducing Bak activation and Bax translocation. Cancer Res. 2007, 67, 782-791. [CrossRef] [PubMed]

5. Konopleva, M.; Contractor, R.; Tsao, T.; Samudio, I.; Ruvolo, P.P.; Kitada, S.; Deng, X.; Zhai, D.; Shi, Y.X.; Sneed, T.; et al. Mechanisms of apoptosis sensitivity and resistance to the BH3 mimetic ABT-737 in acute myeloid leukemia. Cancer Cell 2006, 10, 375-388. [CrossRef] [PubMed]

6. Mason, K.D.; Vandenberg, C.J.; Scott, C.L.; Wei, A.H.; Cory, S.; Huang, D.C.; Roberts, A.W. In Vivo efficacy of the Bcl-2 antagonist ABT-737 against aggressive Myc-driven lymphomas. Proc. Natl. Acad. Sci. USA 2008, 105, 17961-17966. [CrossRef]

7. Kutuk, O.; Letai, A. Alteration of the mitochondrial apoptotic pathway is key to acquired paclitaxel resistance and can be reversed by ABT-737. Cancer Res. 2008, 68, 7985-7994. [CrossRef]

8. Yu, X.; Dobrikov, M.; Keir, S.T.; Gromeier, M.; Pastan, I.H.; Reisfeld, R.; Bigner, D.D.; Chandramohan, V. Synergistic antitumor effects of 9.2.27-PE38KDEL and ABT-737 in primary and metastatic brain tumors. PLoS ONE 2019, 14, e0210608. [CrossRef]

9. Shen, J.; Xu, L.; Zhao, Q. Perifosine and ABT-737 synergistically inhibit lung cancer cells In Vitro and In Vivo. Biochem. Biophys. Res. Commun. 2016, 473, 1170-1176. [CrossRef]

10. Hwang, E.; Hwang, S.H.; Kim, J.; Park, J.H.; Oh, S.; Kim, Y.A.; Hwang, K.T. ABT-737 ameliorates docetaxel resistance in triple negative breast cancer cell line. Ann. Surg. Treat. Res. 2018, 95, 240-248. [CrossRef]

11. Antman, K.H. Introduction: The history of arsenic trioxide in cancer therapy. Oncologist 2001, 6 (Suppl. 2), 1-2. [CrossRef]

12. Kumar, S.; Yedjou, C.G.; Tchounwou, P.B. Arsenic trioxide induces oxidative stress, DNA damage, and mitochondrial pathway of apoptosis in human leukemia (HL-60) cells. J. Exp. Clin. Cancer Res. 2014, 33, 42. [CrossRef] [PubMed]

13. Yu, J.; Qian, H.; Li, Y.; Wang, Y.; Zhang, X.; Liang, X.; Fu, M.; Lin, C. Therapeutic effect of arsenic trioxide $\left(\mathrm{As}_{2} \mathrm{O}_{3}\right)$ on cervical cancer In Vitro and In Vivo through apoptosis induction. Cancer Biol. Ther. 2007, 6, 580-586. [CrossRef] [PubMed]

14. Zhang, L.; Liu, L.; Zhan, S.; Chen, L.; Wang, Y.; Zhang, Y.; Du, J.; Wu, Y.; Gu, L. Arsenic Trioxide Suppressed Migration and Angiogenesis by Targeting FOXO3a in Gastric Cancer Cells. Int. J. Mol. Sci. 2018, 19, 3739. [CrossRef] [PubMed] 
15. Qiu, Y.; Dai, Y.; Zhang, C.; Yang, Y.; Jin, M.; Shan, W.; Shen, J.; Lu, M.; Tang, Z.; Ju, L.; et al. Arsenic trioxide reverses the chemoresistance in hepatocellular carcinoma: A targeted intervention of 14-3-3eta/NF-kappaB feedback loop. J. Exp. Clin. Cancer Res. 2018, 37, 321. [CrossRef] [PubMed]

16. Antignani, A.; Youle, R.J. How do Bax and Bak lead to permeabilization of the outer mitochondrial membrane? Curr. Opin. Cell Biol. 2006, 18, 685-689. [CrossRef] [PubMed]

17. Annis, M.G.; Soucie, E.L.; Dlugosz, P.J.; Cruz-Aguado, J.A.; Penn, L.Z.; Leber, B.; Andrews, D.W. Bax forms multispanning monomers that oligomerize to permeabilize membranes during apoptosis. EMBO J. 2005, 24, 2096-2103. [CrossRef] [PubMed]

18. Dlugosz, P.J.; Billen, L.P.; Annis, M.G.; Zhu, W.; Zhang, Z.; Lin, J.; Leber, B.; Andrews, D.W. Bcl-2 changes conformation to inhibit Bax oligomerization. EMBO J. 2006, 25, 2287-2296. [CrossRef]

19. Shen, H.P.; Wu, W.J.; Ko, J.L.; Wu, T.F.; Yang, S.F.; Wu, C.H.; Yeh, C.M.; Wang, P.H. Effects of ABT-737 combined with irradiation treatment on uterine cervical cancer cells. Oncol. Lett. 2019, 18, 4328-4336. [CrossRef]

20. Hsin, I.L.; Ou, C.C.; Wu, M.F.; Jan, M.S.; Hsiao, Y.M.; Lin, C.H.; Ko, J.L. GMI, an Immunomodulatory Protein from Ganoderma microsporum, Potentiates Cisplatin-Induced Apoptosis via Autophagy in Lung Cancer Cells. Mol. Pharm. 2015, 12, 1534-1543. [CrossRef]

21. Hsin, I.L.; Ou, C.C.; Wu, T.C.; Jan, M.S.; Wu, M.F.; Chiu, L.Y.; Lue, K.H.; Ko, J.L. GMI, an immunomodulatory protein from Ganoderma microsporum, induces autophagy in non-small cell lung cancer cells. Autophagy 2011, 7, 873-882. [CrossRef] [PubMed]

22. Hsin, I.L.; Wang, S.C.; Li, J.R.; Ciou, T.C.; Wu, C.H.; Wu, H.M.; Ko, J.L. Immunomodulatory proteins FIP-gts and chloroquine induce caspase-independent cell death via autophagy for resensitizing cisplatin-resistant urothelial cancer cells. Phytomedicine 2016, 23, 1566-1573. [CrossRef] [PubMed]

23. Hsin, I.L.; Hsu, J.C.; Wu, W.J.; Lu, H.J.; Wu, M.F.; Ko, J.L. GMI, a fungal immunomodulatory protein from Ganoderma microsporum, induce apoptosis via beta-catenin suppression in lung cancer cells. Environ. Toxicol. 2018, 33, 955-961. [CrossRef]

24. St John, J.C.; Amaral, A.; Bowles, E.; Oliveira, J.F.; Lloyd, R.; Freitas, M.; Gray, H.L.; Navara, C.S.; Oliveira, G.; Schatten, G.P.; et al. The analysis of mitochondria and mitochondrial DNA in human embryonic stem cells. Methods Mol. Biol. 2006, 331, 347-374. [CrossRef] [PubMed]

25. Shah, B.P.; Pasquale, N.; De, G.; Tan, T.; Ma, J.; Lee, K.B. Core-shell nanoparticle-based peptide therapeutics and combined hyperthermia for enhanced cancer cell apoptosis. ACS Nano 2014, 8, 9379-9387. [CrossRef] [PubMed]

26. Doherty, J.; Baehrecke, E.H. Life, death and autophagy. Nat. Cell Biol. 2018, 20, 1110-1117. [CrossRef]

27. Filippova, M.; Filippov, V.; Williams, V.M.; Zhang, K.; Kokoza, A.; Bashkirova, S.; Duerksen-Hughes, P. Cellular levels of oxidative stress affect the response of cervical cancer cells to chemotherapeutic agents. Biomed. Res. Int. 2014, 2014, 574659. [CrossRef]

28. Filippova, M.; Brown-Bryan, T.A.; Casiano, C.A.; Duerksen-Hughes, P.J. The human papillomavirus 16 E6 protein can either protect or further sensitize cells to TNF: Effect of dose. Cell Death Differ. 2005, 12, 1622-1635. [CrossRef]

29. Liu, S.S.; Chan, K.Y.; Leung, R.C.; Law, H.K.; Leung, T.W.; Ngan, H.Y. Enhancement of the radiosensitivity of cervical cancer cells by overexpressing p73alpha. Mol. Cancer Ther. 2006, 5, 1209-1215. [CrossRef]

30. Kroemer, G.; Galluzzi, L.; Brenner, C. Mitochondrial membrane permeabilization in cell death. Physiol. Rev. 2007, 87, 99-163. [CrossRef]

31. Gottlob, K.; Majewski, N.; Kennedy, S.; Kandel, E.; Robey, R.B.; Hay, N. Inhibition of early apoptotic events by Akt/PKB is dependent on the first committed step of glycolysis and mitochondrial hexokinase. Genes Dev. 2001, 15, 1406-1418. [CrossRef]

32. Halestrap, A.P.; Richardson, A.P. The mitochondrial permeability transition: A current perspective on its identity and role in ischaemia/reperfusion injury. J. Mol. Cell Cardiol. 2015, 78, 129-141. [CrossRef]

33. Chevrollier, A.; Loiseau, D.; Reynier, P.; Stepien, G. Adenine nucleotide translocase 2 is a key mitochondrial protein in cancer metabolism. Biochim. Biophys. Acta 2011, 1807, 562-567. [CrossRef]

34. Jang, J.Y.; Kim, Y.G.; Nam, S.J.; Keam, B.; Kim, T.M.; Jeon, Y.K.; Kim, C.W. Targeting Adenine Nucleotide Translocase-2 (ANT2) to Overcome Resistance to Epidermal Growth Factor Receptor Tyrosine Kinase Inhibitor in Non-Small Cell Lung Cancer. Mol. Cancer Ther. 2016, 15, 1387-1396. [CrossRef] 
35. Shoshan-Barmatz, V.; De Pinto, V.; Zweckstetter, M.; Raviv, Z.; Keinan, N.; Arbel, N. VDAC, a multi-functional mitochondrial protein regulating cell life and death. Mol. Asp. Med. 2010, 31, 227-285. [CrossRef] [PubMed]

36. Vikstrom, I.B.; Slomp, A.; Carrington, E.M.; Moesbergen, L.M.; Chang, C.; Kelly, G.L.; Glaser, S.P.; Jansen, J.H.; Leusen, J.H.; Strasser, A.; et al. MCL-1 is required throughout B-cell development and its loss sensitizes specific B-cell subsets to inhibition of BCL-2 or BCL-XL. Cell Death Dis. 2016, 7, e2345. [CrossRef] [PubMed]

37. Belmar, J.; Fesik, S.W. Small molecule Mcl-1 inhibitors for the treatment of cancer. Pharmacol. Ther. 2015, 145, 76-84. [CrossRef] [PubMed]

38. Wertz, I.E.; Kusam, S.; Lam, C.; Okamoto, T.; Sandoval, W.; Anderson, D.J.; Helgason, E.; Ernst, J.A.; Eby, M.; Liu, J.; et al. Sensitivity to antitubulin chemotherapeutics is regulated by MCL1 and FBW7. Nature 2011, 471, 110-114. [CrossRef] [PubMed]

39. Wei, S.H.; Dong, K.; Lin, F.; Wang, X.; Li, B.; Shen, J.J.; Zhang, Q.; Wang, R.; Zhang, H.Z. Inducing apoptosis and enhancing chemosensitivity to gemcitabine via RNA interference targeting Mcl-1 gene in pancreatic carcinoma cell. Cancer Chemother. Pharmacol. 2008, 62, 1055-1064. [CrossRef] [PubMed]

40. Pan, R.; Ruvolo, V.R.; Wei, J.; Konopleva, M.; Reed, J.C.; Pellecchia, M.; Andreeff, M.; Ruvolo, P.P. Inhibition of Mcl-1 with the pan-Bcl-2 family inhibitor (-)BI97D6 overcomes ABT-737 resistance in acute myeloid leukemia. Blood 2015, 126, 363-372. [CrossRef] [PubMed]

41. Woo, S.M.; Min, K.J.; Seo, B.R.; Seo, Y.H.; Jeong, Y.J.; Kwon, T.K. YM155 enhances ABT-737-mediated apoptosis through Mcl-1 downregulation in Mcl-1-overexpressed cancer cells. Mol. Cell Biochem. 2017, 429, 91-102. [CrossRef] [PubMed]

42. Sun, X.P.; Zhang, X.; He, C.; Qiao, H.; Jiang, X.; Jiang, H.; Sun, X. ABT-737 synergizes with arsenic trioxide to induce apoptosis of gastric carcinoma cells In Vitro and In Vivo. J. Int. Med. Res. 2012, 40, 1251-1264. [CrossRef] [PubMed]

43. Souers, A.J.; Leverson, J.D.; Boghaert, E.R.; Ackler, S.L.; Catron, N.D.; Chen, J.; Dayton, B.D.; Ding, H.; Enschede, S.H.; Fairbrother, W.J.; et al. ABT-199, a potent and selective BCL-2 inhibitor, achieves antitumor activity while sparing platelets. Nat. Med. 2013, 19, 202-208. [CrossRef] [PubMed]

44. Asghar, U.; Witkiewicz, A.K.; Turner, N.C.; Knudsen, E.S. The history and future of targeting cyclin-dependent kinases in cancer therapy. Nat. Rev. Drug Discov. 2015, 14, 130-146. [CrossRef]

45. Liu, Q.; Hilsenbeck, S.; Gazitt, Y. Arsenic trioxide-induced apoptosis in myeloma cells: p53-dependent G1 or G2/M cell cycle arrest, activation of caspase-8 or caspase-9, and synergy with APO2/TRAIL. Blood 2003, 101, 4078-4087. [CrossRef]

46. Longley, D.B.; Harkin, D.P.; Johnston, P.G. 5-fluorouracil: Mechanisms of action and clinical strategies. Nat. Rev. Cancer 2003, 3, 330-338. [CrossRef]

47. Subbarayan, P.R.; Lee, K.; Ardalan, B. Arsenic trioxide suppresses thymidylate synthase in 5-FU-resistant colorectal cancer cell line HT29 In Vitro re-sensitizing cells to 5-FU. Anticancer Res. 2010, 30, 1157-1162.

48. Wilson, P.M.; Danenberg, P.V.; Johnston, P.G.; Lenz, H.J.; Ladner, R.D. Standing the test of time: Targeting thymidylate biosynthesis in cancer therapy. Nat. Rev. Clin. Oncol. 2014, 11, 282-298. [CrossRef]

49. Gump, J.M.; Thorburn, A. Autophagy and apoptosis: What is the connection? Trends Cell Biol. 2011, 21, 387-392. [CrossRef]

(C) 2019 by the authors. Licensee MDPI, Basel, Switzerland. This article is an open access article distributed under the terms and conditions of the Creative Commons Attribution (CC BY) license (http://creativecommons.org/licenses/by/4.0/). 